\title{
The ubiquitin/proteasome pathway from Lemna minor subjected to heat shock
}

\author{
A.S. CAEIRO ${ }^{1}$, P.C. RAMOS ${ }^{2}$, A.R. TEIXEIRA ${ }^{3}$ and R.B. FERREIRA ${ }^{1,3 *}$ \\ Instituto de Tecnologia Química e Biológica, Universidade Nova de Lisboa, \\ Apartado 127, 2781-901 Oeiras, Portugal ${ }^{1}$ \\ Departamento de Química e Bioquímica, Faculdade de Ciências e Tecnologia, Universidade do Algarve, \\ Faro, Portugal ${ }^{2}$ \\ Departamento de Botânica e Engenharia Biológica, Instituto Superior de Agronomia, \\ Universidade Técnica de Lisboa, 1349-017 Lisboa, Portugal ${ }^{3}$
}

\begin{abstract}
Exposure of Lemna minor L. to high temperatures leads to an initial decrease in the ubiquitin (Ub) monomer pool size and the accumulation of high molecular mass Ub-protein conjugates, possibly reflecting an increment in the supply of protein substrates to the Ub/proteasome pathway. Alternative explanations include, for example, changes in the transcription rates of one or more pathway components. To measure the effect of heat shock on the simultaneous rates of transcription of selected genes encoding five $\mathrm{Ub}$ pathway components $(\mathrm{Ub}, \mathrm{E} 1, \mathrm{E} 2, \beta$ subunit and ATPase subunit of the $26 \mathrm{~S}$ proteasome), a semi-quantitative RT-PCR method was developed using cDNA normalized against the housekeeping gene encoding the $18 \mathrm{~S}$ ribosomal RNA. Whilst Ub transcription is abruptly increased, there is a moderate increment in the transcription of E1 and the $\beta$ subunit, a moderate reduction in the transcription of the ATPase subunit and a marked reduction in the case of E2, indicating a differential transcription pattern of the various components of the $\mathrm{Ub} /$ proteasome pathway in L. minor subjected to high temperatures. These observations suggest that the increment in the $\mathrm{Ub} /$ proteasome pathway intermediates is due to an augmented supply of substrates derived from the stress-induced damage imposed on the cellular proteins. The initial build up of intermediates occurs not only at the expense of the preexisting pool of free $\mathrm{Ub}$, but also as a result of the prompt increase in $\mathrm{Ub}$ expression.
\end{abstract}

Additional key words: ATPase subunit, duckweed, semi-quantitative RT-PCR, transcription.

\section{Introduction}

Plants are typically detrimentally affected upon exposure to high temperatures (Iba 2002). Thus, for example, in mulberry, high temperature stress markedly reduced the activities of Rubisco and sucrose phosphate synthase, decreased chlorophyll, total soluble protein content, photosystem 2 activity and foliar nitrogen and nucleic acids, and affected sugar metabolism through reduction in leaf starch content and sucrose-starch balance (Chaitanya et al. 2001). To cope with the stress, plants have to adapt their protein metabolism promptly, not only by synthesizing a group of stress-related proteins but also by removing damaged or unwanted proteins. Thus, heat shock proteins were synthesized in lentil seeds in response to heat treatment (Dell'Aquila 2000). In strawberry leaves and flowers, the content of most proteins decreased but a few new proteins appeared in response to heat stress (Ledesma et al. 2004). However, this study concluded that the results obtained differ between plant organs and between cultivars. Extracellular proteins were found to accumulate in intercellular spaces of barley primary leaves after heat shock (Tamás et al., 1997). In wheat leaves, the contents in Rubisco activase and Rubisco binding protein were found to increase under heat stress, in accordance with their role as chaperones

Received 26 September 2006, accepted 25 July 2007.

Abbreviations: E1 - Ub-activating enzyme; E2 - Ub-conjugating enzyme; RT-PCR - reverse transcriptase polymerase chain reaction; $\mathrm{Ub}$ - ubiquitin.

Acknowledgements: We thank Dr. José Leitão (Universidade do Algarve, Portugal) for supplying the ubiquitin primers and Cristina Branco Price (University of California, Riverside, USA) for helpful discussions. This work was supported by the Fundação para a Ciência e a Tecnologia, under grant $\mathrm{n}^{\circ}$ PRAXIS XXI/BD/5699/95.

* Author for correspondence; fax: (+351) 214433644, e-mail: rbferreira@itqb.unl.pt 
and the function of the binding protein as a heat shock protein (Demirevska-Kepova et al. 2005).

High temperatures increase the rate of postsynthetic protein denaturation due to the low free energy required to stabilize mature proteins (Goldberg 2003). Partially unfolded proteins can be highly toxic, because they act as nuclei for intracellular aggregation due to the tendency of normally buried hydrophobic domains to associate with one another. For this reason, cellular proteins are under continuous surveillance by the proteolytic systems (Goldberg 2003). The ubiquitin (Ub)/proteasome system, a tightly regulated and highly specific pathway for the degradation of individual proteins in eukaryotic cells, has been reported as a major proteolytic pathway responsible for the selective breakdown of abnormal proteins (Sullivan et al. 2003, Vierstra 2003). Ub-dependent proteolysis of proteins occurs in two sequential steps: tagging the protein substrates with $\mathrm{Ub}$, followed by degradation by the $26 \mathrm{~S}$ proteasome.

The highly conserved, 76-amino-acid protein $\mathrm{Ub}$ is covalently attached to specific protein targets via an ATP-dependent reaction cascade. Subsequent rounds of conjugation add polyUb chains to the target. The Ubconjugating cascade involves the sequential action of three enzyme families, E1, E2 and E3 (Sullivan et al. 2003, Vierstra 2003). The exquisite selectivity of this pathway resides in the $\mathrm{E} 3 \mathrm{~s}$, which are specific for different protein substrates, explaining the large number ( $>1200)$ of E3 genes found in the Arabidopsis genome (Glickman and Ciechanover 2002).

The resulting polyubiquitylated protein conjugates are then recognized and degraded by the $26 \mathrm{~S}$ proteasome, with the concomitant release of the reusable Ub monomers (Vierstra 2003). This ATP-dependent, self-compart-

\section{Materials and methods}

Plant growth and stress induction: Plants of Lemna minor L. were grown at temperature of $21{ }^{\circ} \mathrm{C}$ and a $16-\mathrm{h}$ photoperiod with irradiance of $200 \mu \mathrm{mol}$ (photon) $\mathrm{m}^{-2} \mathrm{~s}^{-1}$ in a complete sterile medium, as described before (Ferreira and Teixeira 1992), supplemented with $10 \mathrm{mM}$ sucrose. For stress induction the plants were incubated at $38{ }^{\circ} \mathrm{C}$ for periods up to $6 \mathrm{~h}$. Plant material was frozen in liquid nitrogen and stored at $-80^{\circ} \mathrm{C}$.

Isolation of total RNA: Total RNA was isolated from plants incubated at $38^{\circ} \mathrm{C}$ during $0,0.5,1,2,3,4$ and $6 \mathrm{~h}$, using the Invisorb Spin Plant-RNA Mini Kit (Invitek, Berlin, Germany), according to the manufacturer's specifications. The RNA was DNase treated using the TURBO DNA-free ${ }^{\mathrm{TM}}$ kit (Ambion, Austin, TX, USA).

Generation of cDNA: Single-stranded complementary DNA (cDNA) was synthesized using the Superscript ${ }^{\mathrm{TM}}$ II RNase $\mathrm{H}$ reverse transcriptase (Invitrogen, Burlington, ON, Canada) according to the manufacturer's protocol. Approximately $250 \mathrm{ng}$ of total RNA was used, in mentalized protease is composed of a $20 \mathrm{~S}$ core protease (CP), in which proteins are degraded to short peptides, and one or two 19S regulatory particles (RP), which confer ATP-dependence and substrate specificity (Voges et al. 1999).

The CP is a broad-spectrum, ATP- and Ub-independent peptidase created by the assembly of four, stacked heptameric rings of related $\alpha$ and $\beta$ subunits surrounding a central cavity. Its two inner $\beta$ rings form a central chamber containing the proteolytic sites, which face the central cavity. Access to this chamber is restricted by a narrow gated channel created by the $\alpha$-subunit rings, which is normally maintained in the closed state. Even in its open state, controlled by the ATPases in the RP, it allows entry of only unfolded proteins (Benaroudj et al. 2003).

Each end of the CP is capped by an RP composed of 18 principal subunits. Apparently, the RP recognizes and binds to polyubiquitylated proteins, releases the attached Ubs as free monomers, unfolds the protein substrates, opens the $\alpha$-subunit ring gate and directs the unfolded proteins into the CP lumen for degradation (Belknap and Garbarino 1996, Voges et al. 1999, Glickman 2000).

Several studies have been published on the effect of stress on the expression of individual $\mathrm{Ub}$ pathway components. However, to our knowledge, no study has been conducted on the various components of the pathway. In this work, the levels of the $\mathrm{Ub}$ pathway intermediates (i.e. free $\mathrm{Ub}$ and the high molecular mass Ub-protein conjugates) were analysed in Lemna minor L. cells subjected to heat shock. Semi-quantitative RT-PCR was then used to follow the changes in the levels of selected mRNAs encoding $\mathrm{Ub}, \mathrm{E} 1, \mathrm{E} 2$, the $\beta$ subunit of the CP, and an ATPase subunit of the RP.

combination with $0.5 \mu \mathrm{g}$ Oligo(dT) $)_{12-18}$ (Invitrogen) and $100 \mathrm{ng}$ of random hexamers $\mathrm{pd}(\mathrm{N})_{6}$ (Roche, Penzberg, Germany) as primers, $500 \mu \mathrm{M}$ of dNTPs (Invitrogen) and $\mathrm{H}_{2} \mathrm{O}$. The mixture was heated at $65^{\circ} \mathrm{C}$ for $5 \mathrm{~min}$ to denature secondary structures, then cooled rapidly in ice and incubated at $25{ }^{\circ} \mathrm{C}$ during $10 \mathrm{~min}$ to allow annealing of random hexamers. The RNA was reverse transcribed in a final volume of $20 \mathrm{~mm}^{3}$ using $200 \mathrm{U}_{\text {Superscript }}^{\mathrm{TM}}$ II RNase $\mathrm{H}$ reverse transcriptase, $40 \mathrm{U}$ RNaseOUT $^{\mathrm{TM}}$ (Invitrogen), $10 \mathrm{mM}$ dithiothreitol (DTT), $4 \mathrm{~mm}^{3} 5 \times$ First-Strand buffer, at $42{ }^{\circ} \mathrm{C}$ for $50 \mathrm{~min}$, and then stopped by heating at $70{ }^{\circ} \mathrm{C}$ for $15 \mathrm{~min}$. The RT mix was incubated with $2 \mathrm{U}$ RNase $\mathrm{H}$ at $37^{\circ} \mathrm{C}$ for $20 \mathrm{~min}$.

Oligonucleotide primers (Table 1) were designed from conserved regions among known selected gene sequences, to amplify specific cDNA sequences encoding five different genes involved in the L. minor $\mathrm{Ub} /$ proteasome pathway. Polymerase chain reactions (PCR) were performed in a Trio-Thermoblock ${ }^{\mathrm{TM}} \mathrm{PCR}$ machine (Biometra, Gottingen, Germany) using $1 \mathrm{~mm}^{3}$ of the 
cDNA, $50 \mathrm{ng}$ of each oligonucleotide primer, $200 \mu \mathrm{M}$ of dNTPs (Invitrogen), 1.25 U of Taq DNA polymerase (Invitrogen) and $5 \mathrm{~mm}^{3} 10 \times$ PCR buffer, in a $50 \mathrm{~mm}^{3}$ volume. The PCR program initially started with a $95^{\circ} \mathrm{C}$ denaturing step for $3 \mathrm{~min}$, followed by $3 \mathrm{~min}$ at the appropriate annealing temperature (a.t. $55^{\circ} \mathrm{C}$ for $\mathrm{Ub}$, $60{ }^{\circ} \mathrm{C}$ for $\mathrm{E} 1,55^{\circ} \mathrm{C}$ for $\mathrm{E} 2,60{ }^{\circ} \mathrm{C}$ for the $\beta$ subunit of the $26 \mathrm{~S}$ proteasome, and $55^{\circ} \mathrm{C}$ for the ATPase subunit of the 26S proteasome) and $72{ }^{\circ} \mathrm{C}$ for $3 \mathrm{~min}$. It continued then with 36 cycles at $95^{\circ} \mathrm{C}$ for $90 \mathrm{~s}$, a.t. for $90 \mathrm{~s}$ and $72{ }^{\circ} \mathrm{C}$ for $90 \mathrm{~s}$, and a final elongation step at $72^{\circ} \mathrm{C}$ for $5 \mathrm{~min}$.

Agarose gel electrophoresis: The RT-PCR products were fractionated on $1.0 \%$ (1.5\% for semi-quantitative analyses) (w/v) agarose gels in TAE buffer $(40 \mathrm{mM}$ Trisacetate ( $\left.\mathrm{pH} 8.5), 2 \mathrm{mM} \mathrm{Na} \mathrm{EDTA}_{2} 2 \mathrm{H}_{2} \mathrm{O}\right)$. The gels were stained with ethidium bromide $\left(0.5 \mathrm{ng} \mathrm{cm}^{-3}\right)$ and the UV illuminated gel images were digitally captured with a CCD-camera from Gel Doc ${ }^{\mathrm{TM}} 1000$ Single Wavelength Mini-Transilluminator (BIO-RAD, Hercules, CA, USA) and acquired using Quantity One $\AA$ version 4.01 program (BIO-RAD, Hercules, CA, USA).

Similarity search: RT-PCR products were purified using the high pure PCR product purification kit (Roche). These products were subsequently sequenced with BigDyeTerminator v1.1 kit (Applied Biosystems, Foster City, CA, USA) and analyzed by multi-capillary electrophoresis with ABI Prism 3700 DNA analyzer at Instituto de Tecnologia Química e Biológica, Universidade Nova de Lisboa, Oeiras, Portugal. DNA sequence similarity was searched at NCBI with the $B L A S T$ 2.2.9 algorithm to confirm identity. New sequences were considered confirmed if they were $>80 \%$ homologous against other plant sequences.

Semi-quantitative PCR: For semi-quantitative PCR (following the protocol provided by Ambion, with minor modifications), and for each cDNA species of interest, the range of cycles over which each species should be examined was initially determined. A PCR master mix was prepared and was split into 10 aliquots, which were then subjected to PCR amplification and removed at different cycle numbers, starting with cycle 24 and ending with cycle 38 . The thermal cycle profile used included a denaturation step of $95^{\circ} \mathrm{C}$ for $3 \mathrm{~min}$, followed by $3 \mathrm{~min}$ annealing, $72^{\circ} \mathrm{C}$ for $3 \mathrm{~min}$, and then by 24 to 38 cycles of $95^{\circ} \mathrm{C}$ for $30 \mathrm{~s}$, a.t. for $30 \mathrm{~s}, 72^{\circ} \mathrm{C}$ for $30 \mathrm{~s}$ and a final elongation at $72{ }^{\circ} \mathrm{C}$ for $5 \mathrm{~min}$. The PCR samples were fractionated on $1.0 \%(\mathrm{~m} / \mathrm{v})$ agarose gels, visualized with ethidium bromide, quantified with Scion Image Beta 4.0.2 program and plotted (log of the signal vs. cycle number). The ideal cycle number selected for subsequent experiments was one in the middle of the detectable linear range.

Subsequently, the cDNAs of interest were coamplified with a "housekeeping" gene (the $18 \mathrm{~S}$ ribosomal RNA; transcript of $315 \mathrm{bp}$ ), for the number of cycles determined before, using commercial primers from QuantumRNATM $18 S$ internal standards (Ambion). Previous to RT-PCR experiments, the ratio of $18 \mathrm{~S}$ primers to competimers (needed to contain both the specific gene and the $18 \mathrm{~S}$ internal control, and to give similar yields of products) was determined using different ratios of $18 \mathrm{~S}$ primer:competimer $(400 \mathrm{nM})$ in the PCR mixture.

PCR was utilized to quantify the relative amount of mRNA, using $1 \mathrm{~mm}^{3}$ of the cDNA template, $50 \mathrm{ng}$ of each gene specific primer pair, $400 \mathrm{nM}$ of $18 \mathrm{~S}$ primers:competimers (Ambion), $200 \mu \mathrm{M}$ of dNTPs, $1.25 \mathrm{U}$ of Taq DNA polymerase and $5 \mathrm{~mm}^{3} 10 \times$ PCR buffer, in a final volume of $50 \mathrm{~mm}^{3}$. The thermal cycle profile was as follows: $95{ }^{\circ} \mathrm{C}$ for $3 \mathrm{~min}$, a.t. for $3 \mathrm{~min}$, $72{ }^{\circ} \mathrm{C}$ for $3 \mathrm{~min}$, followed by 27 to 31 cycles of $95{ }^{\circ} \mathrm{C}$ for $30 \mathrm{~s}$, a.t. for $30 \mathrm{~s}$ and $72{ }^{\circ} \mathrm{C}$ for $30 \mathrm{~s}$, and a final elongation of the product for $5 \mathrm{~min}$ at $72{ }^{\circ} \mathrm{C}$. The RT-PCR products were separated and visualized on $1.5 \%$ $(\mathrm{m} / \mathrm{v})$ agarose gels, and digitally recorded and quantified as previously described. Data were expressed in relation to the internal control, as a ratio of the specified gene signal divided by the $18 \mathrm{~S}$ ribosomal signal, in arbitrary units.

Protein extraction: Proteins were extracted by homogenizing $\left(2 \mathrm{~cm}^{3} \mathrm{~g}^{-1}\right.$ fresh mass) plant samples in $90 \mathrm{mM}$ Tris- $\mathrm{HCl}$ buffer ( $\mathrm{pH} 8.0)$, containing $45 \%$ (v/v) ethylene glycol, $18 \mathrm{mM}$ sodium disulphite, $10 \mathrm{mM}$ $N$-ethyl-maleimide (NEM), $5 \mathrm{mM}$ ethylene diaminetetraacetic acid (EDTA), and $1 \mathrm{mM}$ phenyl methyl sulfonyl fluoride (PMSF). The homogenate was then squeezed through two layers of cheesecloth and centrifuged at $31000 \mathrm{~g}$ for $12 \mathrm{~min}$. The resulting supernatant was desalted into $25 \mathrm{mM}$ Tris-HCl buffer ( $\mathrm{pH}$ 7.4), containing $150 \mathrm{mM} \mathrm{NaCl}, 1 \mathrm{mM}$ EDTA, and $10 \mathrm{mM}$ NEM. Protein concentrations were estimated by the Bradford method, using bovine serum albumin (BSA) as the standard.

Electrophoresis and Western blotting: Protein samples $(5 \mu \mathrm{g})$ were subjected to sodium dodecyl sulphatepolyacrylamide gel electrophoresis (SDS-PAGE). To perform the Western analysis, the separated proteins were subsequently transfered onto a polyvinylidene fluoride (PVDF) membrane (Roche). Immunoblotting was performed according to the standard procedures described previously (Ferreira and Shaw 1989). Enhanced chemiluminescence (ECL) was used as the detection system (Pierce, Erembodegem, Belgium). Ub-P conjugates and free ubiquitin were semi-quantified using GelPlot facility from Scion Image for Windows (version Beta 4.0.2, Scion Corporation).

Statistical analyses: RT-PCR values were averaged from 3 replicates and are reported as the mean $\pm \mathrm{SE}$. For the analysis of variance and for Post-hoc comparison of mean, Tukey honest significant difference (HSD) test and Statistica ${ }^{\circledR} 6.0$ software were used. 


\section{Results and discussion}

Selection of the genes encoding Ub/proteasome pathway components: It is well known that many $\mathrm{Ub}$ pathway components are encoded by multigene families. For example, Arabidopsis contains two E1 genes, 37 E2 genes and $\sim 1300$ encoding E3 components (Vierstra 2003). However, in some cases, the encoding genes exhibit a high degree of homology, whereas in others only a small subset is responsive under stress conditions.

Different criteria were followed to design the primers. Amplification primers (Table 1) were designed on highly conserved regions, including protein motifs whenever possible. Because Ub, E1 and E2 are encoded by gene families (Smalle and Vierstra 2004), an attempt was made to select polyUb, E1 and E2 genes whose levels of transcripts have been reported in the literature to be affected by stress (Seufert and Jentsch 1990, Girod et al. 1993, Hatfield et al. 1997, Loser and Weltring 1998, Noventa-Jordao et al. 2000, Spees et al. 2002a,b).

Ubiquitin is encoded by a multigene family. Functional $\mathrm{Ub}$ is produced from two different types of $\mathrm{Ub}$ genes, namely polyUb genes an $\mathrm{Ub}$ extension genes (Schlesinger and Bond 1987, Callis and Vierstra 1989). PolyUb genes contain tandem head-to-tail repeats of 228 bp encoding the Ub protein. In the case of Pisum sativum, for example, four polyUb genes (PUB1, PUB2, PUB3 and $P U B 4$ ) were isolated from a genomic library and completely sequenced (Xia and Mahon 1998). Ub extension genes contain a single $\mathrm{Ub}$ repeat followed in frame by sequences encoding one of two ribosomal proteins. The initial translation products from both types of $\mathrm{Ub}$ genes are readily processed to intact, functional $\mathrm{Ub}$ monomers.

The Ub extension protein genes are not generally involved in stress responses (Hoffman et al. 1991, Rickey and Belknap 1991). On the contrary, polyUb genes have been shown to be transcriptionally activated by heat stress in a variety of plants, animals and fungi (Genschik et al. 1992, Myer and Schwartz 1996, Sun and Callis 1997, Loser and Weltring 1998, Rollfinke et al. 1998, Simon et al. 1999). However, heat stress induced the transcription of only specific members of the polyUb gene family in several species (Belknap and Garbarino 1996, Noventa-Jordao et al. 2000, Spees et al. 2002a).

The Lemna Ub sequence to be amplified was selected to target the Ub domain signature (PS00299), making the primers specific to polyUb transcripts, while excluding the Ub-fusion transcripts. In addition, the primers obtained originate multiple matching subsegments (products) in the polyUb mRNAs, reflecting the $\mathrm{Ub}$ repeats in the sequence. Thus, in the case of Lemna, three polyUb gene products were obtained (results not shown) with sizes estimated at 250, 500 and $750 \mathrm{bp}$. The multiple matching obtained experimentally for Lemna was compared with the theoretical multiple matching obtained for the four polyUb genes from $P$. sativum (GenBank accession numbers L81139, L81140, L81141 and L81142; Xia and Mahon 1998). To this end, the primers designed for Lemna polyUb genes were aligned with the $P$. sativum polyUb gene sequences (BLAST 2 sequences) and the range of amplified products predicted: three products $(234,462$ and $690 \mathrm{bp})$ for $P U B 2$, two products (234 and $462 \mathrm{bp}$ ) for $P U B 3$, one product (234 bp) for $P U B 4$ and no product for PUB1. These observations indicate that the products obtained from Lemna probably represent a pool of polyUb transcripts synthesized from different polyUb genes.

Multiple E1 isoforms exist in organisms. Thus, E1s are encoded by one gene in Saccharomyces cerevisiae, by two genes in Arabidopsis thaliana, or by three genes in Triticum aestivum. The two Arabidopsis E1 genes have been reported to be co-expressed in most, if not all, plant tissues and cells and not differentially expressed (Hatfield and Vierstra 1992, Hatfield et al. 1997). Since the number of E1 encoding genes in Lemna remains unknown, primers were designed that are potentially capable of amplifying the total pool of E1 transcripts. To this end, the region of the sequence to be amplified contained the prosite motif Ub-activating enzyme active site (PS00865).

Table 1. Sequence of primers and expected fragment size of RT-PCR products, used in the semi-quantitative RT-PCR analysis of mRNA levels of the genes expressed in Lemna minor in response to heat stress. The GenBank accession numbers for the cDNA partial sequences obtained in this work for $L$. minor genes are indicated.

\begin{tabular}{|c|c|c|c|}
\hline Gene & Sequences of primers & Size $[b p]$ & Number \\
\hline Polyubiquitin & $\begin{array}{l}\text { Sense: 5'-TAGACAATGTTAAGGCCAAGATTCAAGACAAGG-3' } \\
\text { Antisense: } \text { 5' }^{\prime} \text { - TGTCAATGGTATCAGAGCTCTCCACCTCAAGGG -3' }\end{array}$ & 234 & AY 683447 \\
\hline $\begin{array}{l}\text { Ubiquitin-activating } \\
\text { enzyme (E1) }\end{array}$ & $\begin{array}{l}\text { Sense: 5'-GGCAAGAATGTATGTTGACCAG-3' } \\
\text { Antisense: 5'-TGTGGGGAACGAGTGAGAGT-3' }\end{array}$ & 180 & AY 683450 \\
\hline $\begin{array}{l}\text { Ubiquitin-conjugating } \\
\text { enzyme (E2) }\end{array}$ & $\begin{array}{l}\text { Sense: } 5^{\prime} \text {-CCAAGCGCATCCTCAAGGAGCTCAAGG-3' } \\
\text { Antisense: } 5^{\prime} \text {-GGATAATCTGGAGGAAAATGAATGGTAACC-3 }\end{array}$ & 175 & AY 683451 \\
\hline $\begin{array}{l}\text { Beta subunit of the } 26 \mathrm{~S} \\
\text { proteasome }\end{array}$ & $\begin{array}{l}\text { Sense: 5'-CCATGGCTGGTGGGGCTGCTGAC-3' } \\
\text { Antisense: 5'-CCAGGCCCCGTTTCATCCCACCC-3' }\end{array}$ & 199 & AY 683448 \\
\hline $\begin{array}{l}\text { ATPase subunit of the } \\
26 \mathrm{~S} \text { proteasome }\end{array}$ & $\begin{array}{l}\text { Sense: } 5^{\prime} \text {-GGTTCGACGCACGTGGCAACATCAAGG-3' } \\
\text { Antisense: 5'- CCTAATGTCGGCACCTGTGGAGTTTGG-3 }\end{array}$ & 236 & AY683446 \\
\hline
\end{tabular}



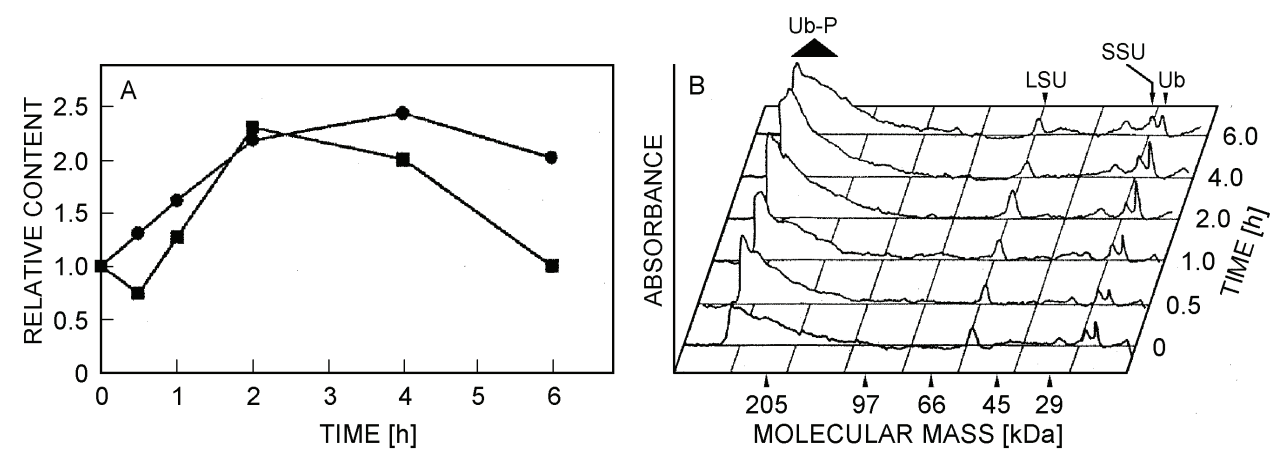

Fig. 1. Immunoblot quantification of the levels of free $\mathrm{Ub}(\mathrm{Ub})$ and high molecular mass Ub-protein conjugates (Ub-P) in Lemna minor exposed to $38^{\circ} \mathrm{C}$ for different periods of time (from 0 to $6 \mathrm{~h}$ ). $A$ - Relative content of free Ub (squares) and Ub-protein conjugates (circles). B - Profile plots generated for each lane in the immunoblot where the total Lemna protein was probed with anti$\mathrm{Ub}$ antibodies; the data presented were averaged from several immunoblots. Molecular masses of standards in kDa; LSU and SSU large and small subunits of ribulose bisphosphate carboxylase.

The various isoforms of E2s are all encoded by small multigene families containing from two to more than five members (Seufert and Jentsch 1990, Zhang et al. 2003). The primers to the Lemna E2 gene sequence were designed to target the prosite motif of the Ub-conjugating enzyme family (PS50127).

In the case of the $26 \mathrm{~S}$ proteasome, all genes encoding its subunits have been reported to be expressed simultaneously and up-regulated under stress conditions (Belknap and Garbarino 1996, Smalle and Vierstra 2004). RT-PCR analysis using suitable primers (Table 1) allowed the amplification of $236 \mathrm{bp}$ and $199 \mathrm{bp}$ fragments for the ATPase and $\beta$ subunit of the $26 \mathrm{~S}$ proteasome, respectively. The deduced amino acid sequence from the L. minor $26 \mathrm{~S}$ proteasome ATPase subunit fragment contains a prosite motif AAA-protein family signature (PS00674).

Changes in the levels of Ub/proteasome pathway intermediates in Lemna minor in response to heat shock: The average relative (considering the values obtained for the control without heat stress as unit) contents of free $\mathrm{Ub}$ and high molecular mass Ub-protein conjugates were determined in plants of $L$. minor exposed to $38^{\circ} \mathrm{C}$ for $0,0.5,1,2,3,4$ and $6 \mathrm{~h}$ (Fig. $1 A, B$ ). These diagrams were prepared from several immunoblots that were probed with affinity chromatography purified, antiUb polyclonal antibodies. As noted before (Ferreira et al. 1995) these antibodies produced a measurable signal with the large (LSU) and small (SSU) subunits of Rubisco (Fig. 1).

As expected, heat shock induced a gradual build-up of large $\mathrm{Ub}$ conjugates in the intracellulars (Fig. 1). As concerns free $\mathrm{Ub}$, there was a rapid reduction in its content following the onset of stress, possibly explained by a prompt demand for this protein to the ubiquitylation of heat-unfolded proteins. The subsequent boost in the in vivo content of free $\mathrm{Ub}$ might result from a large increase in its level of expression plus rate of release from the Ub conjugates, which exceeded during several hours its rate of conjugation. These results are supported by the previous observation that $\mathrm{Ub}$ is itself a heat shock protein (Bond and Schlesinger 1985).

It now seems well established that high temperatures, as other stresses in general, lead to decreased $\mathrm{Ub}$ monomer pool size and the accumulation of high molecular mass Ub-protein conjugates in plant tissues (Ferguson et al. 1990), possibly by increasing the supply of protein substrates to the Ub/proteasome pathway. In the particular case of heat shock, many proteins suffer partial unfolding and become toxic because of their tendency to form intracellular aggregates. For this reason, cellular proteins are under constant surveillance by the proteolytic systems, which continually monitor mature proteins for postsynthetic denaturation (Goldberg 2003). Indeed, the Ub/proteasome pathway is believed to function during heat stress by degrading the enhanced levels of damaged cellular proteins. However, alternative explanations for the observed decrease in free $\mathrm{Ub} /$ increase in Ub-conjugates during heat stress, such as, for example, a reduction in the expression and/or an increment in the proteolysis of one or more of the pathway components, cannot be ruled out.

Changes in the levels of selected mRNAs encoding $\mathrm{Ub} /$ proteasome pathway components in Lemna minor in response to heat shock: The information concerning the expression under stress conditions of the various $\mathrm{Ub} /$ proteasome pathway components as a whole is sparse. Most studies have focused on individual pathway components. Nevertheless, resistance to high temperatures in yeast has been shown to require both the synthesis of $\mathrm{Ub}$ monomers and other components of the Ub-conjugating system and the proteasome (Finley et al. 1987, Hilt and Wolf 1995).

Using suitable primers, designed from conserved regions among known gene sequences, a study was conducted to follow the changes in the levels of selected mRNAs encoding various $\mathrm{Ub} /$ proteasome pathway components (Ub, E1, E2, and $\beta$ subunit from the $\mathrm{CP}$ and ATPase subunit from the RP of the proteasome) in L. minor exposed to high temperatures $\left(38^{\circ} \mathrm{C}\right)$ for various 
durations. After isolation of the total RNA fraction from each plant sample, RT-PCR was used to select and amplify specific cDNA sequences encoding the genes of interest. With the exception of $\mathrm{Ub}$, for which three amplification products of the expected size were produced (see above), after conventional PCR performed under optimized conditions (data not shown) and for each primer pair tested, a single amplification product of the expected size was obtained. The amplified products or PCR amplicons were subsequently sequenced and the corresponding deduced amino acid sequences compared with those of other species (results not shown). These data indicate that there are very strong homologies when

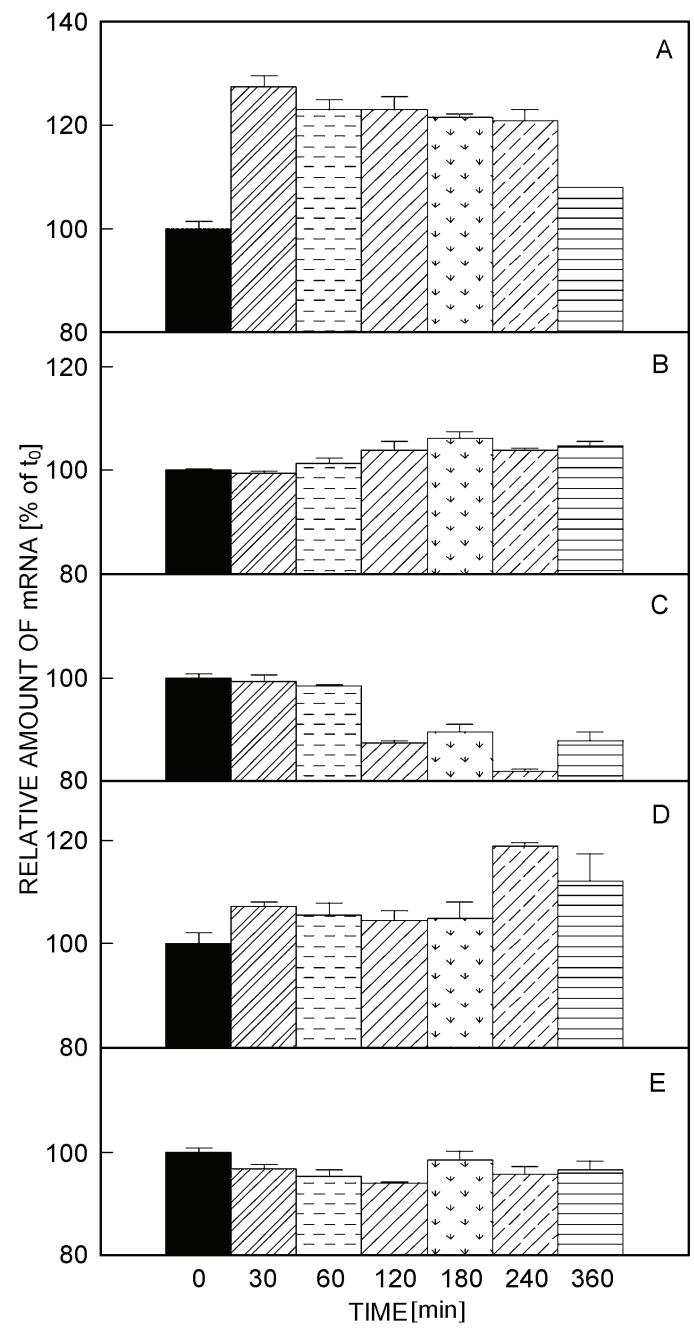

Fig. 2. Effect of heat stress on the relative amounts of the mRNAs encoding the five selected genes involved in the ubiquitin/proteasome pathway from Lemna minor. The plants were exposed to $38{ }^{\circ} \mathrm{C}$ for $0,0.5,1,2,3,4$ and $6 \mathrm{~h}$. $A$ - ubiquitin; $B-\mathrm{E} 1 ; C-\mathrm{E} 2 ; D-\beta$ subunit of the $26 \mathrm{~S}$ proteasome; $E$ - ATPase subunit of the $26 \mathrm{~S}$ proteasome. Relative amounts of mRNA were measured by semiquantitative RT-PCR. Means \pm SE. Significant differences from the $0 \mathrm{~h}$ are marked as $* *(\mathrm{P}<0.01)$ and $* * *(\mathrm{P}<0.001)$. the amino acid sequences of the five proteins under study are compared with those of the other species, including man.

The primers specific for the polyUb, E1, E2, $\beta$ subunit and ATPase genes were designed to span 234, 180, 175, 199 and 236 bp of the cDNA, respectively (Table 1). To follow the changes in the levels of the transcribed mRNAs in L. minor subjected to heat shock, a semiquantitative RT-PCR method was developed using cDNA normalized against the housekeeping gene encoding the $18 \mathrm{~S}$ ribosomal RNA (transcript of $315 \mathrm{bp}$ ). This method did not require radioactivity or expensive PCR instruments with real-time fluorescent detection (Meadus 2003). RT-PCR values were presented as a ratio of the specified gene's signal in the selected linear amplification cycle divided by the $18 \mathrm{~S}$ ribosomal RNA signal.

The results of this experiment showed that there was an abrupt increase in the transcription of polyUb soon after the onset of stress, followed by a gradual decline thereafter (Fig. 2). However, the contents of polyUb mRNA were always above the control value. Moderate increases were observed for $\mathrm{E} 1$ and the $\beta$ subunit of the proteasome. A moderate decrease was detected in the transcription of the ATPase subunit of the proteasome, and a marked reduction in the case of E2.

In the case of the $26 \mathrm{~S}$ proteasome, all genes encoding its subunits have been reported to be expressed simultaneously and up-regulated under stress conditions (Belknap and Garbarino 1996, Smalle and Vierstra 2004). Ito et al. (1997) detected the simultaneous expression of the $\alpha$ and $\beta$ subunits of the CP and an ATPase subunit of the RP during germination of Spinacia oleracea seeds. These observations contrast with the data presented in Fig. 2, in which the content of the $\beta$ subunit mRNA increased and that of the ATPase subunit decreased when Lemna was exposed to heat shock. Shirley and Godman (Shirley and Goodman 1993) had already reported that a limited increase in mRNA encoding a proteasome subunit was induced by heat shock in Arabidopsis. In support of our results are the studies performed by Basset et al. (2002), who showed that both 20S and 26S forms coexisted in eukaryotic cells (Yang et al. 1995). Besides its functions as the proteolytic core of the $26 \mathrm{~S}$ complex, the $20 \mathrm{~S}$ proteasome may be involved in the degradation of oxidatively modified proteins (Basset et al. 2002), forming a selective mechanism to remove oxidatively damaged proteins from the cell (Grune et al. 1997). If this hypothesis is correct, it is not surprising to find differential expression patterns between CP and RP subunits, at least under selected conditions.

With the exception of the 26S proteasome subunits, the other results (Fig. 2) are in reasonable agreement with the scarce information available on this subject in the literature. Heat stress has been shown to result in transcriptional activation of polyUb genes in a variety of plant species (Belknap and Garbarino 1996). However, in several plant species, such as potato, maize and sunflower, only specific members of the polyUb gene 
family are transcriptionally activated by heat stress. Furthermore, polyUb genes that are either nonresponsive or down-regulated by heat shock have also been identified in Arabidopsis and parsley (Belknap and Garbarino 1996). Although the genes of certain E2s are transcriptionally activated by heat shock in animals (Goldberg 2003) and yeast (Seufert and Jentsch 1990),

\section{References}

Basset, G., Raymond, P., Malek, L., Brouquisse, R.: Changes in the expression and the enzymic properties of the $20 \mathrm{~S}$ proteasome in sugar-starved maize roots. Evidence for an in vivo oxidation of the proteasome. - Plant Physiol. 128: 1149-1162, 2002.

Belknap, W.R., Garbarino, J.E.: The role of ubiquitin in plant senescence and stress responses. - Trends Plant Sci. 1: 331335, 1996.

Benaroudj, N., Zwickl, P., Seemüller, E., Baumeister, W., Goldberg, A.L.: ATP hydrolysis by the proteasome regulatory complex PAN serves multiple functions in protein degradation. - Mol. cell. Biol. 11: 69-78, 2003.

Bond, U., Schlesinger, M.J.: Ubiquitin is a heat shock protein in chicken embryo fibroblasts. - Mol. cell. Biol. 5: 949-956, 1985.

Callis, J., Vierstra, R.D.: Ubiquitin and ubiquitin genes in higher plants. - Oxford Survey Plant mol. Biol. 6: 1-30, 1989.

Chaitanya, K.V., Sundar, D., Reddy, A.R.: Mulberry leaf metabolism under high temperature stress. - Biol. Plant. 44: 379-384, 2004.

Dell'Aquila, A.: Effect of combined salt and heat treatments on germination and heat-shock protein synthesis in lentil seeds. - Biol. Plant. 43: 591-594, 2000.

Demirevska-Kepova, K., Holzer, R., Simova-Stoilova, L., Feller, U.: Heat stress effects on ribulose-1,5-bisphosphate carboxylase/oxygenase, Rubisco binding protein and Rubisco activase in wheat leaves. - Biol. Plant. 49: 521-525, 2005.

Ferguson, D.I., Guikema, J.A., Paulsen, G.M.: Ubiquitin pool modulation and protein degradation in wheat roots during high temperature stress. - Plant Physiol. 92: 740-746, 1990.

Ferreira, R.B., Shaw, N.M.: Effect of osmotic stress on protein turnover in Lemna minor fronds. - Planta 179: 456-465, 1989.

Ferreira, R.B., Teixeira, A.R.: Sulfur starvation in Lemna leads to degradation of ribulose-bisphosphate carboxylase without plant death. - J. biol. Chem. 267: 7253-7257, 1992.

Ferreira, R.M., Ramos, P.C., Franco, E., Ricardo, C.P., Teixeira, A.R.: Changes in ubiquitin and ubiquitin-protein conjugates during seed formation and germination. - J. exp. Bot. 46: 211-219, 1995.

Finley, D., Ozkaynak, E., Varshavsky, A.: The yeast polyubiquitin gene is essential for resistence to high temperatures, starvation, and other stresses. - Cell 48: 1035$1046,1987$.

Genschik, P., Durr, A., Fleck, J.: Differential expression of several E2-type ubiquitin carrier protein genes at different developmental stages in Arabidopsis thaliana and Nicotiana sylvestris - Mol. gen. Genet. 244: 548-555, 1994.

Genschik, P., Parmentier, Y., Durr, A., Marbach, J., Criqui, M.C., Jamet, E., Fleck, J.: Ubiquitin genes are differentially regulated in protoplast-derived cultures of Nicotiana their plant homologs are not induced by high temperatures in either Arabidopsis (Sullivan et al. 1994) or Nicotiana sylvestris (Genschik et al. 1994).

In summary, the data illustrated in Fig. 2 indicate a differential expression of the various components of the $\mathrm{Ub} /$ proteasome pathway in Lemna minor exposed to high temperatures. sylvestris and in response to various stresses. - Plant mol. Biol. 20: 897-910, 1992.

Glickman, M.H., Ciechanover, A.: The ubiquitin-proteasome proteolytic pathway: destruction for the sake of construction. - Physiol. Rev. 82: 373-428, 2002.

Glickman, M.H.: Getting in and out of the proteasome. - Semin. Cell Dev. Biol. 11: 149-158, 2000.

Goldberg, A.L.: Protein degradation and protection against misfolded or damaged proteins. - Nature 426: 895-899, 2003.

Grune, T., Reinheckel, T., Davies, K.J.: Degradation of oxidized proteins in mammalian cells. - FASEB J. 11: 526534, 1997.

Hatfield, P.M., Gosink, M.M., Carpenter, T.B., Vierstra, R.D.: The ubiquitin-activating enzyme (E1) gene family in Arabidopsis thaliana. - Plant J. 11: 213-226, 1997.

Hatfield, P.M., Vierstra, R.D.: Multiple forms of ubiquitinactivating enzyme E1 from wheat. Identification of an essential cysteine by in vitro mutagenesis. - J. biol. Chem. 267: 14799-14803, 1992.

Hilt, W., Wolf, D.H.: Proteasomes of the yeast S. cerevisiae: genes, structure and functions. - Mol. Biol. Rep. 21: 3-10, 1995.

Hoffman, N.E., Ko, K., Milkowski, D., Pichersky, E.: Isolation and char,acterization of tomato cDNA and genomic clones encoding the ubiquitin gene ubi3. - Plant mol. Biol. 17: 1189-1201, 1991.

Iba, K.: Acclimative response to temperature stress in higher plants: approaches of gene engineering for temperature tolerance. - Annu. Rev. Plant Biol. 53: 225-245, 2002.

Ito, N., Tomizawa, K., Tanaka, K., Matsui, M., Kendrick, R.E., Sato, T., Nakagawa, H.: Characterization of $26 \mathrm{~S}$ proteasome alpha- and beta-type and ATPase subunits from spinach and their expression during early stages of seedling development. - Plant mol. Biol. 34: 307-316, 1997.

Ledesma , N.A., Kawabata, S., Sugiyama, N.: Effect of high temperature on protein expression in strawberry plants. Biol. Plant. 48: 73-79, 2004.

Loser, K., Weltring, K.-M.: Induction of a polyubiquitin gene (ubil) by potato phytoalexins and heat shock in Gibberella pulicaris. - Curr. Genet. 34: 404-409, 1998.

Meadus, W.J.: A semi-quantitative RT-PCR method to measure the in vivo effect of dietary conjugated linoleic acid on porcine muscle PPAR gene expression. - Biol. Proc. Online 5: 20-28, 2003.

Myer, A., Schwartz, L.M.: Allelic variation of the polyubiquitin gene in the tobacco hawkmoth, Manduca sexta, and its regulation by heat shock and programmed cell death. Insect Biochem. mol. Biol. 26: 1037-1046, 1996.

Noventa-Jordao, M.A., Nascimento, A.M., Goldman, M.H., Terenzi, H.F., Goldman, G.H.: Molecular characterization of ubiquitin genes from Aspergillus nidulans: mRNA expression on different stress and growth conditions. - 


\section{A.S. CAEIRO et al.}

Biochem. biophys. Acta 1490: 237-244, 2000.

Rickey, T.M., Belknap, W.R.: Comparison of the expression of several stress-responsive genes in potato tuber. - Plant mol. Biol. 16: 1009-1018, 1991.

Rollfinke, I.K., Silber, M.V., Pfitzner, U.M.: Characterization and expression of a heptaubiquitin gene from tomato. Gene 211: 267-276, 1998 .

Schlesinger, M.J., Bond, U.: Ubiquitin genes. - Oxford Surveys Eukaryotic Genes 4: 77-89, 1987.

Seufert, W., Jentsch, S.: Ubiquitin-conjugating enzymes UBC4 and UBC5 mediate selective degradation of short-lived and abnormal proteins. - EMBO J. 9: 543-550, 1990.

Shirley, B.W., Goodman, H.M.: An Arabidopsis gene homologous to mammalian and insect genes encoding the largest proteasome subunit. - Mol. gen. Genet. 241: 586594, 1993.

Simon, J.R., Treger, J.M., McEntee, K.: Multiple independent regulatory pathways control UBI4 expression after heat shock in Saccharomyces cerevisiae. - Mol. Microbiol. 31: 823-832, 1999.

Smalle, J., Vierstra, R.D.: The ubiquitin 26s proteasome proteolytic pathway. - Annu. Rev. Plant Biol. 55: 555-590, 2004.

Spees, J.L., Chan, S.A., Snyder, M.J., Chang, E.S.: Osmotic induction of stress-responsive gene expression in the lobster Homarus americanus. - Biol. Bull. 203: 331-337, 2002a.

Spees, J.L., Chan, S.A., Snyder, M.J., Chang, E.S.: Thermal acclimation and stress in the American lobster, Homarus americanus: equivalent temperature shifts elicit unique gene expression patterns for molecular chaperones and polyubiquitin. - Cell Stress Chaperones 7: 97-106, 2002 b.
Sullivan, J.A., Shirasu, K., Deng, X.W.: The diverse roles of ubiquitin and the $26 \mathrm{~S}$ proteasome in the life of plants. Nature Rev. Genet. 4: 948-958, 2003.

Sullivan, M.L., Carpenter, T.B., Vierstra, R.D.: Homologues of wheat ubiquitin-conjugating enzymes TaUBC1 and TaUBC4 are encoded by small multigene families in Arabidopsis thaliana. - Plant mol. Biol. 24: 651-661, 1994.

Sun, C.W., Callis, J.: Independent modulation of Arabidopsis thaliana polyubiquitin mRNAs in different organs and in response to environmental changes. - Plant J. 11: 10171027, 1997.

Tamás, L., Huttová, J., Zigová, Z.: Accumulation of stressproteins in intercellular spaces of barley leaves induced by biotic and abiotic factors. - Biol. Plant. 39: 387-394, 1997.

Vierstra, R.D.: The ubiquitin/26S proteasome pathway, the complex last chapter in the life of many plant proteins. Trends Plant Sci. 8: 135-142, 2003.

Voges, D., Zwickl, P., Baumeister, W.: The 26S proteasome: a molecular machine designed for controlled proteolysis. Annu. Rev. Biochem. 68: 1015-1068, 1999.

Xia, X., Mahon, J.: Pea polyubiquitin genes: (I) structure and genomic organization. - Gene 215: 445-452, 1998.

Yang, Y., Früh, K., Ahn, K., Peterson, P.A.: In vivo assembly of the proteasomal complexes, implications for antigen processing. - J. biol. Chem. 270: 27687-27694, 1995.

Zhang, X.D., Jenkins, J.N., Callahan, F.E., Creech, R.G., Si, Y., McCarty, J.C., Saha, S., Ma, D.P.: Molecular cloning, differential expression, and functional characterization of a family of class I ubiquitin-conjugating enzyme (E2) genes in cotton (Gossypium). - Biochem. biophys. Acta 1625: 269$279,2003$. 